Boise State University

ScholarWorks

$1-1-2018$

\title{
Mythologies of the Artist in Modern India: Cinema, Melodrama and Ravi Varma
}

Niharika Dinkar

Boise State University 
This is an author-produced, peer-reviewed version of this article. The final, definitive version of this document can be found in The

Mediatization of the Artist, published by Palgrave Macmillian. Copyright restrictions may apply.

\title{
Mythologies of the Artist in Modern India: Cinema, Melodrama and Ravi Varma
}

\author{
Niharika Dinkar \\ Boise State University
}

Although the Indian artist Ravi Varma (1948-1906) was much celebrated during his lifetime, and not quite forgotten after his death in 1906, in the last decade there has been a true revival of interest in his life and work. In 2008 Ketan Mehta directed a Hindi film Rang Rasiya (Colours of Passion) based on the life of the celebrated Indian painter. ${ }^{1}$ Another fictionalized biographical sketch of the artist, this time in book form, The Painter: A Life of Ravi Varma by Deepanjana Pal, followed in 2009 and was directed towards a broad audience. In 2010 a more scholarly treatment of Varma's life and work was published under the title Raja Ravi Varma: Painter of Colonial India; it was written by Rupika Chawla, who had curated a major retrospective of the artist in 1993 at the National Museum in Delhi. This exhibition had provided a major impetus for the reconsideration of the artist's work in the annals of modern Indian art. A second film on his life and work in Malayalam followed in 2010; entitled Makaramanju (The Mist of Capricorn) and directed by Lenin Rajendran it was then dubbed in Tamil as Apsaras (2011). 2013 marked the arrival of an English translation of a romantic Marathi biography (Raja Ravi Varma, 2013) by the writer Ranjit Desai. It was this publication that served as the source of both the films produced on Ravi Varma.

All of these recent engagements with Ravi Varma have (to varying degrees) been invested in the artist's life as a major source for understanding his creative process and the encounter between "tradition" and the ideals of freedom of expression that have defined discussions of art in the public sphere in India in recent years. The current revival of interest in Ravi Varma is perhaps timely given the burgeoning Indian art market and its interest in the past; the campy recognition of Ravi Varma as the father of kitsch; the re-evaluation of the modern Indian art movement in exhibitions and academia; and discussions about global modernity. However, what is distinctive in this public re-imagination of Ravi Varma is the manner in which he is resurrected as the figure of the "Romantic Artist" - his life and work interwoven into a mythical narrative that speaks of the arrival of modern Indian art into public consciousness.

\section{Artistic Personhood and Indian Art}

The myths and legends surrounding the life of Ravi Varma are not new and have been well acknowledged. Even in his earliest biographies we find apocryphal stories about a child-genius given to coloring the walls in his house, mastering the skills of oil painting on his own, even taming a wild elephant (a feat with a long history in the Indian imagination, extending from Buddha to the Mughal emperor Akbar). Celebrated as the first modern Indian artist during his lifetime, these and other myths served to bolster nationalist claims for the existence of Indian "fine arts". As Geeta Kapur has pointed out, "The fact and fiction of Ravi Varma's struggle to learn oil painting becomes a legend. Here is not only the struggle of the artist to gain a technique but the struggle of a native to gain the source of his master's superior knowledge, and the struggle of the prodigy to steal the fire for his own people."2 For Christopher Pinney, the persistence of the myth of Ravi Varma can be related to his image as both the patriarch of high art and the purveyor of cheap artifact (through the inexpensive oleographic prints he popularized). These two antagonistic narratives keeping interest alive in the riddle that he symbolized. ${ }^{3}$

Integral to the myth of Ravi Varma has been the story of his life as an artist, and it is not accidental that the recent presentations of his work have closely dwelt on the biographical. The focus on the individual as representative of his art is all the more striking because of the general anonymity of the pre-modern Indian artist, where style, religion, geographic region, or the patron's vision have been seen as the defining features of the artwork, rather than the individual persona. Recent art-historical scholarship has tended to view this anonymity as a shortcoming and has attempted to rectify it by identifying Mughal and Pahari artists from the sixteenth to the eighteenth centuries and

\footnotetext{
${ }^{1}$ The film was only released in 2014 because it failed to get clearance from the Indian Censor Board, thanks to its many erotic scenes and the idea that such scenes were unsuitable for public audiences.

${ }^{2}$ Geeta Kapur, “Representational Dilemmas of a Nineteenth Century Indian Painter”, Journal of Arts and Ideas No. 17-18:1989, 60.

${ }^{3}$ Christopher Pinney, Photos of the Gods (New Delhi: Oxford University Press, 2004), 60-62.
} 
This is an author-produced, peer-reviewed version of this article. The final, definitive version of this document can be found in The Mediatization of the Artist, published by Palgrave Macmillian. Copyright restrictions may apply.

providing extended biographical analyses, to take just two examples. ${ }^{4}$ This move from anonymity to identification is related to an unacknowledged privileging of the individuality of the artist as the sole author of the work. In sixteenthcentury Akbari painting, for example, as many as three different artists could be employed to paint the same picture, one for the rangzimi (coloring), another for the tarh (composition) with yet another for the chihranami (the painting of faces). When artists were credited for their work it was more likely in order to distribute the payments, and when artists worked individually their decisions were based on their specializations in different genres (portraiture, flowers and animals, etc.). ${ }^{5}$ In any case, rather than reflecting the subjective intentions of the singular artist or the sole vision of the patron, a complex set of cultural choices was seen to have informed the vision of the artist.

The problems surrounding artistic personhood, however, point to the larger issue of the framing of individual identity in South Asia, where collective categories of caste, religion, nation or family have tended to dominate sociological analysis. Louis Dumont famously mapped the rise of individualism in the West against the "traditional society" of India, where the interdependence amongst members served to constrain the rise of an autonomous self. ${ }^{6}$ The debates around Fredric Jameson's identification of third-world literature as a "national allegory" have continued to address questions as to how one might consider individualism and subjectivity outside the Western world. ${ }^{7}$ More recent examinations of individualized Indian identity have come from investigations into the genres of biography and autobiography, where issues of selfhood and individual agency are paramount, although they do not necessarily correspond to Western conventions and modes of expression. ${ }^{8}$ Could one, in the same vein, examine what role the myth of the artist plays in the imagination of an individual identity?

Standing at the supposed origins of modern Indian art, the myths surrounding Ravi Varma celebrate him not just as a named artist but as an exemplary individual, bearing all the signs of creative genius, one in whose image the very notion of the modern artist is written. This conflation between the modern artist and individualized identity is not particular to Ravi Varma and in fact recent art-historical scholarship has tended to view the artist as the paradigmatic figure of the modern subject. Grant Kester's work on the emergence of individualism in European thought has made arguments about the simultaneous rise of modern artistic identity in seventeenth- century intellectual history. ${ }^{9}$ Amelia Jones traces the cult of the artist to a more recent past, locating it in the nineteenth century, following the impact of Jacob Burckhardt's influential theses on Renaissance individualism and Kantian and Hegelian notions of art and freedom. ${ }^{10}$ Donald Preziosi's analysis of the film Lust for Life explores modern mythologies of artistic identity indicating how a "Vasarian auteurist ideology" was invoked in the "fixing [of] the artist-hero on the sunlit stainedglass of homogeneous Selfhood". ${ }^{11}$

In the case of Ravi Varma, his privileged semi-aristocratic life, his proximity to both the British elite and Indian royalty, and the aura of a Westernized notion of the artist were all-instrumental in the fashioning of his persona as a visionary artist. This was a marked departure from the social status of the professional painter in nineteenth-century India, which was tied closely to the fortunes of his patrons. ${ }^{12}$ In an acknowledgement of the changing status of the

\footnotetext{
${ }^{4}$ See John Guy, and Jorrit Britschgi (eds)., Wonder of the Age: Master Painters of India, 1100-1900 (New York: Metropolitan Museum of Art, 2011); and Eberhard Fischer and B.N. Goswamy, Nainsukh of Guler: A Great Indian Painter from a small Hill State (Delhi: Niyogi Books, 2012). ${ }^{5}$ Gregory Minissale, Images of Thought: Visuality in Islamic India 1550-1750 (Newcastle: Cambridge Scholars Press, 2006$), 3-4$.

${ }^{6}$ Louis Dumont, Essays on Individualism: Modern Ideology in Anthropological Perspective (Chicago and London: University of Chicago Press, 1986). For a critique of Dumont's views, see Nicholas Dirks, Castes of Mind: Colonialism and the Making of Modern India (Princeton: Princeton University Press, 2001).

${ }^{7}$ Fredric Jameson, “Third-World Literature in the Era of Multinational Capitalism”, Social Text, volume (Autumn, 1986) 15: 65-88; Aijaz Ahmad, "Jameson's Rhetoric of Otherness and the "National Allegory", Social Text , volume (Autumn, 1987) 17: 3-25; Michael Sprinker, "The National Question: Said, Ahmad, Jameson Public Culture, Volume 6 (1993) No. 1: 3-29; Imre Szeman, "Whose Afraid of National Allegory? Jameson, Literary Criticism, Globalization”, The South Atlantic Quarterly, 100 (Summer 2001) 3: 803-827; Julie McGonegal, "Postcolonial Metacritique”, Interventions, 7 (2005) 2: 251-265; Srinivas Aravamudan, "In the Wake of the Novel: The Oriental Tale as National Allegory", NOVEL: A Forum on Fiction, 33 (1999) 1: 5-31.

${ }^{8}$ See Vijaya Ramaswamy and Yogesh Sharma (eds.), Biography as History: Indian Perspectives, (Delhi: Orient Blackswan, 2008), David Arnold and Stuart H. Blackburn (eds.), Telling Lives in India: Biography, Autobiography, and Life History (Bloomington: Indiana University Press, 2004), and Partha Chatterjee and Raziuddin Aquil, History in the Vernacular (Delhi: Permanent Black, 2008).

${ }^{9}$ Grant H. Kester, The One and the Many: Contemporary Collaborative Art in a Global Context (Durham: Duke University Press, 2011)

${ }^{10}$ Amelia Jones, Seeing Differently: A history and theory of identification and the visual arts (New York: Routledge, 2012)

${ }^{11}$ Donald Preziosi, "That Obscure Object of Desire" in Rethinking Art History: Meditations on a Coy Science (New Haven and London: Yale University Press, 1989), 26.

${ }^{12}$ Art historical discussions from early India have pointed to painting as one of the sixty-four arts specified by Vastyayana in his Kamasutra including amongst others carpentry, architecture, conjuring tricks and the arts of hairdressing. Most historians agree that through much of the historical past the artist did not enjoy a high reputation in the social hierarchy although a proximity to royal patrons granted him a somewhat higher standing. From this perspective then, as Stella Kramrisch suggests, there was in fact, no strict differentiation between the artist and the craftsman. Stella Kramrisch, “Artist, Patron, and Public in India”, The Far Eastern Quarterly, 15 (1956) 3: 335-342. See also, Michael W. Meister (ed.),
} 
This is an author-produced, peer-reviewed version of this article. The final, definitive version of this document can be found in The Mediatization of the Artist, published by Palgrave Macmillian. Copyright restrictions may apply.

artist in the then-contemporary Indian imagination, an essay on Ravi Varma's career in The Modern Review in 1907 described him as the greatest artist of modern India, a nation-builder who showed the moral courage of a gifted "highborn" by taking up the "degrading profession of painting." 13 This latter was an idea that had persisted throughout Varma's lifetime. An anonymous biography published in 1903 stated that: "Though painting was considered in those days a degrading profession for a gentleman, the enlightened Maharaja, under whom Travancore first came to be known as a 'model state,' thought quite otherwise. His Highness found great promise in the boy and extended his patronage to him [...]"14 The common assumption regarding the profession of painting as unbecoming of the aristocratic class was repeated in obituaries of the artist after his death. ${ }^{15}$ S.N. Joshi, who published a collection of his oleographs in 1911 agreed that Ravi Varma's choice of career was an anomaly in royal families: "In those days the profession of a portrait painter or even of a gifted artist was looked down upon as being not quite worthy of a son of a princely house.” 16

What contributed to the change in the stature of the artist and what was Ravi Varma's own role in this transformation? On the one hand, his aristocratic background and proximity to royal patrons granted him a profile quite unlike the artists from more modest backgrounds churned out by colonial art schools. The heroic narrative of "the Artist" that has canonized him in the popular imagination as the "painter prince" seized upon precisely these elements, establishing him as a worthy native who could equal the colonial master. However, what has been equally prominent in the reception of Ravi Varma has been the romantic mythologization of his persona. In what ways did these mythologies link creative activity and the individual self? Taking the case of recent cinematic biographies of the artist, we will now examine how these mythologies were invested in the production of the artistic subject upon a landscape where general anonymity pervaded the painter's life.

\section{Melodramatic Cinema and the Artist Subject}

Griselda Pollock has noted how the artist-hero of both the novel (Irving Stone, 1934) and the film Lust for Life (dir. Vincente Minnelli, 1956) is actually the discipline of art history itself, with the cinematic biography performing an important ideological role for a wider public. Lust for Life presents Dutch painter Vincent van Gogh (1853-1890) as a tragic artist-hero whose creativity and individuality is signaled through periodic bouts of madness and lucidity, with the art historian as the privileged mediator between the "mad genius" and the audience. Pollock contends that "the preoccupation with the individual artist is symptomatic of the work accomplished in art history - the production of an artistic 'subject for works of art'; in this case the 'mad genius' whose vision is reflexively bound into the work of art, so that art is presented as a personal vision rather than as historically and socially conditioned. ${ }^{17}$

The portrayal of Ravi Varma in contemporary cinematic representations conjoins art and artist, adopting a melodramatic idiom familiar to viewers of Bombay cinema and which directly resonates with a wider public. It refrains, however, from the tortured subjective inwardness of its European counterpart. Art and artist are bound together in a common goal - the pursuit of a freedom that necessarily transgresses the bounds of conventional morality. As my reading of the films will demonstrate, the artistic subject produced is not the isolated mad genius out of step with the world, but rather a creative visionary comfortable with the hurly burly of modern life, who speaks in favor of sexual and imaginative freedom, invoking history and mythology to buttress his claims. In this sense, art does not present itself as a purely autonomous domain but is rather intimately connected with the world, while the artist is posited as a man who has truer knowledge of the past and promises its authentic translation in the present. Further, as I argue artistic identity is expressly constructed on the impulses of a masculine desire that is emotionally invested in the female muse.

Making Things in South Asia: The Role of Artist and Craftsman, Proceedings of the South Asia Seminar IV (Philadelphia: Department of South Asia Regional Studies, University of Pennsylvania, 1989).

${ }^{13}$ Ramanand Chatterjee, The Modern Review, 1907, reprinted in Raja Ravi Varma (New Delhi: National Museum, 1993), 144-146.

${ }^{14}$ Ravi Varma The Indian Artist (Allahabad: The Indian Press, 1903), 2-3. The author is unknown but is suspected to be Ramanand Chatterjee, who was an editor at The Modern Review.

${ }^{15}$ The Madras Times concurred: "Mr. Ravi Varma, whose death we recorded yesterday, was of high descent, being a near relation of the ruling family of Travancore, which makes it all the more to his credit that he devoted his life to hard work at his art.” 5 October 1906, 8.

${ }^{16}$ S. N. Joshi, Half-Tone Reprints of the Renowned Pictures of the Late Raja Ravivarma: With a Short Sketch of his Life, and Description of every Picture (Poona: S.N. Joshi, 1911), 1-2.

${ }^{17}$ Griselda Pollock, “Artists mythologies and media genius, madness and art history”, Screen 21 (1980) 3: 57-96. 
This is an author-produced, peer-reviewed version of this article. The final, definitive version of this document can be found in The Mediatization of the Artist, published by Palgrave Macmillian. Copyright restrictions may apply.

Cinema from the city of Mumbai (formerly Bombay) has been the subject of much attention, both scholarly and popular, and given the appellation "Bollywood" in recent years. Despite its dominant pan-Indian and international presence, it remains one amidst the many regional film industries in India. The two films on Ravi Varma include one from Bombay (Rang Rasiya), while the second (Makaramanju) is a product of the Malayalam film industry from Ravi Varma's home state. The Tamil redubbing of Makaramanju introduces the film to Tamil film audiences, a neighboring film industry with a distinctive presence in southern India. Crossover films and actors between the various film industries are common, however I will restrict my examination here largely to Hindi cinema from Bombay given its pan Indian reach and the corresponding claims for Ravi Varma as an 'Indian’ painter (rather than a Malayali painter).

There are only a few precedents in Hindi cinema from Bombay that feature an artist, the most notable examples being from the genre of historical films produced in the 1940s and 1950s, portraying stories from the Mughal era. Poetry was an important aspect of courtly culture and is well recognized in these films, which lionize the poet; the visual artist, however, is seen much more rarely. In both Shah Jehan(1946) and Mughal-e-Azam(1960), the artists presented are, strangely enough, sculptors. This is highly anachronistic as few examples of sculpture exist from the Mughal period, which is best known for its painting, calligraphy and architecture and certainly not for the kind of lifelike marble sculpture featured in both films.

In the grand visual spectacle Mughal-e-Azam, the sculptor is an unkempt outsider who claims to be the voice of conscience, criticizing the excesses of the emperor Akbar while acknowledging that his fate for exposing the truth might result in his death by imperial decree. Notably, Mughal-e-Azam features the classic trope of the work of art coming to life, in this case a veiled courtesan (Anarkali), who substitutes for the statue that the sculptor has not yet completed. We later learn that the sculptor never intended to finish the statue. This twist on the characteristic relationship between art and life - which typically envisions the artist as possessing godlike powers of creation - is here undone by proposing life as fundamentally more interesting than anything the artist could ever create. ${ }^{18}$ With her beauty and grace, the muse Anarkali seduces not only the artist and the young prince Jahangir in the film but also the viewer, as the camera dwells lovingly on her face while she shakes the very foundations of the Mughal empire. This triangulated relationship between the artist, the muse and the work of art takes a different turn in the films based on the life of Ravi Varma, which follow a pattern more reminiscent of the Westernized nineteenth- century model of the artist, with its focus on the creative powers of the painter and the subordination of the female body to its painted guise. It is, in fact, this subjection of life to art that authorizes the painter and grants him his identity as creative visionary.

Ranjit Desai's sentimentalized Marathi retelling of the story of Ravi Varma has inspired two cinematic versions, one in Malayalam (Makaramanju/The Mist of Capricorn) and one in Hindi (Rang Rasiya/Colours of Passion), both exhibiting key features of melodrama, echoing the primary aesthetic mode of Ravi Varma's mythological paintings. In typical melodramatic idiom, the films present sensational drama and violent appeals to emotion, centered on the artist-hero whose unique personality holds the key to a moral truth that is revealed through the course of the film. This truth is of course the liberating discourse of art, whose moral authority is the driving force of the narrative and whose valiant defender is personified in the artist-hero. Film scholarship has noted how both melodrama and stardom are conceptually similar, drawing on individual presence to narrate a simplified morality tale. ${ }^{19}$ If melodrama channels broad social change and conflict through an individual embodiment of ethical action, stars appeal because they present this through the drama of the body rather than psychological interiorization. As such, both are associated with the ideology of individualism and a mode of performance that externalizes emotion, so that body and gesture are more suggestive of meaning than narrative structure. The celebrity artist- hero provides a point of convergence for these two parallel modes associated with cinema granting him a larger than life iconic stature.

In a context where the figure of the artist was largely invisible and certainly did not enjoy a high social standing outside elitist cultural circles, melodrama serves as a particularly apt mode to tell the story of the emergence of the artist-hero. Ketan Mehta's Rang Rasiya frames the story of Ravi Varma through an entirely fictional court case charging the painter with obscenity. A painting featuring his muse depicts a partially undressed female mythological character, which causes much consternation in conservative society, so much, so that Ravi Varma is legally charged with hurting religious sentiments. The hearing provides Ravi Varma an opportunity to present his case for art, which

\footnotetext{
${ }^{18}$ Ashish Nandy has elaborated upon this relationship between art and life, between the sculpture and the artist in "Dilip Kumar made me do it" in Ashish Nandy (ed.), The Secret Politics of Our Desires: Innocence, Culpability and Indian Popular Cinema (Delhi: Oxford University Press, 1998), 25-28.

${ }^{19}$ See Christine Gledhill, “Signs of Melodrama”, in Christine Gledhill (ed.), Stardom: Industry of Desire (London: Routledge, 1991$), 207$-229.
} 
This is an author-produced, peer-reviewed version of this article. The final, definitive version of this document can be found in The Mediatization of the Artist, published by Palgrave Macmillian. Copyright restrictions may apply.

he announces as one that encompasses unfettered freedom of the imagination. He wins the case but his muse and beloved commits suicide because her character and reputation are besmirched in the process - a martyr to the cause of art.

Ketan Mehta expressly wove the narrative including the court case to allegorically reference a contemporary trial in the Indian media: that of the famous modernist painter M. F. Husain (1915-2011). Husain has since the late 1990s been singled out for his paintings of nude Hindu goddesses, which were seen as offensive by the Hindu right. ${ }^{20}$ His exhibitions were vandalized, his paintings destroyed and he was forced to seek exile in Qatar, where he passed away in 2011. In Rang Rasiya, Ketan Mehta proposes a similar situation - with conservative forces questioning Ravi Varma's depiction of gods and goddesses. Ravi Varma's courageous defense of his practice allowed him to make a case for the freedoms of art that Mehta proposed were due to Husain as well.

The court case has been a common narrative device in Hollywood biopics allowing the conflict to be telescoped into a dramatic sequence between two sharply opposed sides that then delivers a moral lesson. ${ }^{21}$ Here it gives a space to the artist- hero, allowing him to stage his often-unconventional ideas to a jury comprised not only of the characters in the film, but also of the wider public - the viewers of the film whose judgment is ultimately at stake. In Bombay cinema the courtroom scene has a long history as a venue for justice marked by dramatic revelations and twists of fate, and Mehta's deliberate inclusion of the fictional trial scene in Rang Rasiya poses the artist's representational quest (both Ravi Varma's and Husain's) as a moral and legal question for the nation, to be decided through its ritualized norms of the court and its laws. The trial thus dramatizes questions of painterly form and content, transposing them from a private realm of ideas to questions of national importance involving life and death. The trial scenes allow for a convenient reenactment of primal events allowing the artist-hero to shape audience opinion by the rhetoric of his own performance. George Custen has argued that despite advocating for social change, Hollywood biopics clung to a safe space of experimentation, using narrative strategies like romantic plots to personalize and defang the threatening aspects of change. ${ }^{22}$ And indeed, despite the courageous battle of ideas presented in the trial, Ketan Mehta's reliance upon conventional tropes of the artist's muse as lover reinforces stereotypes of male privilege associated with the artist genius.

\section{Female Bodies and Artistic Autonomy}

While Mehta frames the allegory in terms of a battle between orthodox religion and the autonomous freedom of art, it is apparent that this freedom revolves around a license with female bodies both representational and real. In Rang Rasiya, Ravi Varma is shown accompanied by numerous adoring women, one of whom becomes his muse, while his own wife and children are barely represented in the narrative. The first time we see Ravi Varma painting, he is standing praying before a canvas, getting ready to paint his newly-wed wife. She chides him for pursuing a lowly vocation and he angrily gives it (and her) up, only to be seduced by the physical charms of a maid in the household, Kamini, whom he uses as a model for his early genre paintings depicting regional beauties. “Am I only a painting for you?” she asks coquettishly as they dance around the Kerala countryside with the playback crooning, "I've lost my mind in the temple of your body [...] waking up my long buried dreams." Later in the film this dalliance is explained as an example of Ravi Varma's progressive thinking, as he disregards the bodily caste proscriptions that forbade higher caste members like himself from consorting with lower castes like Kamini.

As he moves to Bombay from his native Travancore, we encounter Ravi Varma's second muse, Sugandha, modeled on the courtesan Anjanibai (dates unknown), who was rumored to have posed for a large number of his paintings. His relationship with her results in the production of several mythological paintings, which picture her in various states of undress, even as they develop a passionate affair, kissing with ardor in the gallery of his first public exhibition. The film here adopts a different tone from previous analyses that had resisted depicting Ravi Varma's amorous engagements. E.M.J. Veniyoor's biography of 1981, for example, had sought to rescue Ravi Varma from charges of promiscuity in his dealings with models from disreputable backgrounds. Referring to his relationship with Anjanibai, Veniyoor writes:

\footnotetext{
${ }^{20}$ Some early responses to the Husain affair include Shohini Ghosh, "Censorship Myths and Imagined Harms” in The Sarai Reader 4: Crisis/ Media (2004), 447-454, and Monica Juneja, "Reclaiming, the Public Sphere. Husain's Portrayals of Saraswati and Draupadi”, Economic and Political Weekly 32/4 (25 January 1997): 155-157. Further sustained examination was undertaken in Sumathi Ramaswamy (ed.), Barefoot Across the Nation: Maqbool Fida Husain \& the Idea of India (New Delhi: Routledge, 2010).

${ }^{21}$ See George F. Custen, Bio/Pics: How Hollywood Constructed Public History (New Brunswick: Rutgers University Press, 1992).

${ }^{22}$ George F. Custen, Bio/Pics, 186-192.
} 
This is an author-produced, peer-reviewed version of this article. The final, definitive version of this document can be found in The Mediatization of the Artist, published by Palgrave Macmillian. Copyright restrictions may apply.

"She was a dancer and a singer and, according to her own confession, men sought her for their bed after a concert and she had a difficult time eluding their clutches. But not so Ravi Varma. He used to advise the men who came to his studio to treat her like a mother or a sister." 23

Veniyoor goes on to explain Ravi Varma's interest in the female body as resulting from the influence of medieval Malayalam Manipravalam erotic poetry, providing a credible artistic source for his passion for the female form in his paintings but refusing to extend that into his personal life. The Sanskrit-based literary culture that comprised Manipravalam texts was, however, not an aesthetic divorced from social life. It was in fact an extension of the courtesan culture of Kerala, where women ritually married to the deity of a temple formed sexual relationships with Brahmins and other high caste men. Manipravalam poetry celebrates this tradition, praising the institutions of courtesanship and the women who comprised it with unrestrained panegyrics to the female body. The poetry was in fact based on a socio-political context of connubial relations that established and perpetuated caste and gender hierarchies. $^{24}$

That director Ketan Mehta then not only acknowledges but even flaunts Ravi Varma's relationships with women - so much so that we often see muses jealous of the others' claims over him - signals a change in the (cinematic) presentation of the artist. It is here that melodrama's penchant for excessive personalization may be seen to converge with the charisma of stardom, with the artist-hero embodying and enacting the caste and gender privileges that were merely chronicled in previous biographies. The dramatic action organizes itself around these privileges as the artisthero mobilizes multiple female bodies around his persona. In case we had forgotten that he was a high caste man, we see the artist reminding us by appending the title Raja to his name, a title that reinforces his aristocratic lineage by association rather than any rights of inheritance. ${ }^{25}$ Surrounded by a bevy of beautiful women, both on canvas and in real life the artist, as portrayed on screen, extends these privileges of ownership over female bodies, appropriating them within the newly emerging domain of high art. This takes a historical scope as he tours across the breadth of the country confronting the famous depictions of erotic art at the Khajuraho temple, which grant him historical precedence to experiment with eroticized women's bodies. ${ }^{26}$

As if historical precedence and evocation of a literary tradition of eroticism was not enough, we see the artist delve into mythology to provide additional context for his semi-naked muses. One scene in the film portrays Ravi Varma lost in thought, as he tells Sugandha of the legend of Urvashi, a heavenly nymph who fell in love with the mortal Pururavas. ${ }^{27}$ The gods consented to their marriage on the condition that neither could see the other in their true guise, i.e. naked. This, however, occurred one evening as Urvashi was getting ready to leave and a bolt of lightning lit up the sky, illuminating her naked body and thus forcing her to leave her mortal husband for the heavens. ${ }^{28}$ Ravi Varma fulminates against social conventions that ban him from painting such beautiful love stories because of the lack of suitable models who would be willing to "face the truth of nudity." The dramatic retelling of the tale has the desired effect of convincing the naïve Sugandha of the importance of recreating such beautiful tales of the past and she unbuttons her blouse to reveal her breast, striking an imaginative pose depicting the departing Urvashi - itself based on a well-known print by Ravi Varma (Urvashi, 1896). Not surprisingly, this leads to a love scene and the uneasy alliance between art and eroticism is rendered explicit as they paint each other's bodies. Paint serves as an adhesive joining their bodies, its fusion of colors providing an alternative garment that covers the "truth" of their nudity. ${ }^{29}$ Set against the backdrop of the canvas and the paint splattered floor of the studio and surrounded by his paintings, art functions as a medium that brings together this passionate love, Rang Rasiya. Translated as Colours of Passion for

\footnotetext{
${ }^{23}$ E.M.J. Veniyoor, Raja Ravi Varma (Trivandrum, Government of Kerala, 1981), 49-50

${ }^{24}$ Rich Freeman, "Genre and Culture Literary Culture of Premodern Kerala" in Sheldon Pollock (ed.), Literary Cultures in History: Reconstructions from South Asia (Berkeley: University of California Press, 2003), 437-500.

${ }^{25}$ Despite the story of Ravi Varma’s progressive attitude towards Kamini, he was an upper caste Hindu man who maintained many forms of ritual purity including never travelling across the oceans to view Western art even though he was much influenced by it, or traveling with a Brahmin cook for his commissions across India.

${ }^{26}$ Manipravalam poetry is not mentioned here as perhaps too esoteric for film audiences and Khajuraho's naked eroticism serves as a more obvious example that appeals to a broader pan Indian audience rather than the Malayalam poetry of his native Kerala.

${ }^{27}$ Makaramanju takes up the same episode from Ranjit Desai's book as its central theme and the tragic relationship between Urvashi and Pururavas is shown as a parallel story to that of Ravi Varma and his muse.

${ }^{28}$ In an interesting inversion of the actual myth, Ketan Mehta's version of the story envisions Urvashi naked, whereas the original story had Pururavas running after her pet lamb in the dark as lightning strikes, so that she sees him naked instead. This inversion reverts the dynamics of seeing within the familiar formula of the male gaze, so that Urvashi remains its object rather than the bearer of the gaze.

${ }^{29}$ Not surprisingly, it is these erotic scenes that have found their way onto youtube, as emblematic of the artist and his lifestyle. Numerous pages advertise the "bold" and "uncensored" love scenes with the footnote that it is based on the life of the famous artist.
} 
This is an author-produced, peer-reviewed version of this article. The final, definitive version of this document can be found in The Mediatization of the Artist, published by Palgrave Macmillian. Copyright restrictions may apply.

the English version of the film, the word rasa draws upon an ancient theory of aesthetic pleasure from the Natyashastra (c. 200 BCE-200 AD), casting the artist as one who is drawn to the pleasure of color and the product of an aesthetics that derives legitimacy from an ancient source.

The female body remains central to the act of painting - both in its painted guise as well as in flesh and blood, so much so that we rarely see other genres like portraiture, which was in fact a mainstay of Ravi Varma's practice and the main source of his income. Equivalences and comparisons between the painted and the real body form the major source of conflict in the film. When Sunanda is shamed for her semi- nude paintings, which have leaked into public view, she attacks Ravi Varma, calling him a leech that sucks life out of a person and warning him that art has the ability to take life away. "You don't exist outside my imagination," he cruelly retorts, reducing her to her painted guise and rendering her self non-existent. It is this subordination of life to art, of the female self to the creative powers of the artist that ties the representation of Ravi Varma to the familiar trope of the genius-artist familiar to nineteenthcentury painting and artistic discourse. ${ }^{30}$ Despite the presence of consistently adoring muses and sensuous painted figures throughout the film, the physical body remains a problem that can only be resolved by Sugandha's suicide, pitting art against life, the imagination against the material, and the artist's act as necessarily implicated in violence. Acknowledging the problem of the female body as a contested site, the director Ketan Mehta has remarked, "It is the Kurukshetra”, invoking the legendary battlefield from the epic, Mahabharata.”31

This image of the Romantic artist whose questioning of conservative society has revolved around sexual freedoms now extends across to contemporary Bombay cinema as well. The painter as a heroic character had been a rare phenomenon in Bombay cinema and despite the popularity of the trope of the tragic poet questioning society, the painter was never quite invoked in the same manner. ${ }^{32}$ In the last fifteen years, however, "new Bollywood," as it has been called, has introduced the artist as a bona- fide character in its stories. Taare Zameen Par (dir. Aamir Khan, 2007) is the heartwarming story of a dyslexic child using drawing as a means of expression. Dhobi Ghat (dir. Kiran Rao, 2010) is an alternative independent film that looks at the city of Mumbai as fabricated by images of its inhabitants - a photographer, a housewife making a video, and a painter who belongs to the world of art exhibitions and openings. Finally, Dil Chahta Hai (dir. Farhan Akhtar, 2001) is a "bromance" between three urban Mumbai boys and their coming of age, where one of the characters is an artist whose unconventional romance with an older woman is presented as indicative of his artistic freedoms. She conveniently dies in the end, leaving him to pursue a more suitable romantic partner in line with conventional morality.

The contemporary incarnation of the artist in Bombay cinema has a distinctly different flavor than the 1950s salutation of the romantic artist. New Bollywood is characterized by a glossy, slick look that bears the marks of neoliberal capital financing, and its narratives have catered to the urban metropolitan viewer rather than the mass publics of the earlier era. The artist is moreover present on television shows that cater to collectors (NDTV's Art Insider), and in interviews that feature young artists (NDTV's On Art), as well as in glamorous magazine spreads designed to appeal to an elite for whom buying art is an investment option. It is not uncommon for press coverage on artists to feature the price of a work per square foot. ${ }^{33}$ All this is a far cry from the penurious romantic artist of Mughal-e-Azam, whose idealism was the most striking feature of his personality.

In this milieu of the glamorous artist, the search for an historical precedent acquires relevance and Ravi Varma's unique position as an aristocratic painter who mastered the skills of oil painting finds an audience looking for a heroic figure from the past. I am not proposing that the celebratory narration of Ravi Varma's life has in fact influenced contemporary cinema and its incorporation of the figure of the artist. However, the current figuration of the artist in cinema together with the simultaneous biographical narrations of Ravi Varma's life are indicative of the entry of the

\footnotetext{
${ }^{30}$ See Catherine M. Sousloff, The Absolute Artist: The Historiography of a Concept (Minneapolis: University of Minnesota Press, 1997), and Ernst Kris and Otto Kurz, Legend, Myth, and Magic in the Image of the Artist: A Historical Experiment (New Haven and London: Yale University Press, 1981).

${ }^{31}$ The ancient epic Mahabharata was widely visualized in painting (including by Ravi Varma) and was an important aspect of social memory in nineteenth-century India. Kurukshetra was the legendary battlefield upon which the central conflict takes place in the Mahabharata.

${ }^{32}$ See Niharika Dinkar, "Rang Rasiya - Conversations with Ketan Mehta”, Marg 62 (2011) 24: p. 72-77xx-xx, xx?

${ }^{33}$ Kishore Singh, "A House for Subodh and Bharti”, Business Standard, 28 July 2012. http://www.business-standard.com/article/beyondbusiness/a-house-for-subodh-bharti-112072800001_1.html URL Accessed 1 October, 2016.
} 
This is an author-produced, peer-reviewed version of this article. The final, definitive version of this document can be found in The Mediatization of the Artist, published by Palgrave Macmillian. Copyright restrictions may apply.

modern artist into the popular imagination beyond the daily cycle of newsprint and magazine spreads. A creative visionary associated with imaginative and sexual freedoms in line with Western histories, the modern Indian artist is certainly a legitimate figure in the media, even as his place in global modern art remains somewhat disputed. 